INDEPENDENT JOURNAL OF MANAGEMENT \& PRODUCTION (IJM\&P) http://www.ijmp.jor.br

v. 5, n. 2, February - May 2014. ISSN: 2236-269X

DOI: 10.14807/ijmp.v5i2.114

\title{
PRODUCTIVITY AND PRESENTEEISM - A QUESTION OF SLEEPING WELL
}

\author{
Renata da S. Cardoso R. Tavares \\ Universidade de Taubaté (UNITAU), Brazil \\ E-mail: renata_cardoso20@hotmail.com \\ Quésia Postigo Kamimura \\ Universidade de Taubaté (UNITAU), Brazil \\ E-mail:qkamimura@gmail.com
}

Submission: 01/08/2013

Revision: 26/08/2013

Accept: 24/10/2013

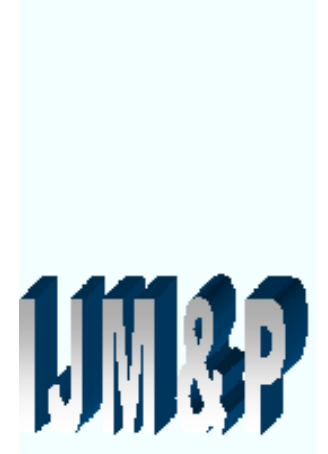

\section{ABSTRACT}

Workers are the main assets of the organization, thereby, having a look at some ways that may interfere with their productivity, represents a strategic move. Thus, we aimed to investigate the frequency of certain factors which interfere in the work of the employees, such as: health problems / illnesses, existence of a sick family member, financial problems, work environment, psychological / emotional and sleep problems. The research was conducted in a manufacturing industry located in the Valley of Paraiba, where a form was applied to a sample of 125 employees. The results were that among the factors surveyed, sleep is what most affects employees' productivity, followed by working environment, and the factor that interferes less being the emotional one. It was observed that seniority interferes with the sleep quality. Thus, it is recognized that sleep interferes with workers' productivity, and it is considered a factor that impacts on their productivity.

KEYWORDS: Efficiency; Presenteeism; Sleep; Personnel

Management; Organizational Case Studies.

Contributors and Supporting Agencies: Capes

[http://creativecommons.org/licenses/by/3.0/us/]

Licensed under a Creative Commons Attribution 3.0 United States License 
INDEPENDENT JOURNAL OF MANAGEMENT \& PRODUCTION (IJM\&P) http://www.ijmp.jor.br

v. 5, n. 2, February - May 2014. ISSN: 2236-269X

DOI: 10.14807/ijmp.v5i2.114

\section{INTRODUCTION}

In terms of human capital management, major business concerns are relate to avoiding accidents, high health costs, high rates of absenteeism and presenteeism and reduced production workers. It is understood that employees represent the human capital of a company and who contribute to its success, in other words, the company depends on that human capital's productivity. Vargas (2008) argues that human capital is important to the company, regardless of the industry type, and it is the main factor that management should put more effort to manage.

Currently, the authors underestimate the total cost of workers' illnesses, which lost a great opportunity to create competitive advantage between firms (HEMP, 2004; BURTON; BRANDT-RAUF, 2008). Programs targeted to the behavior and habits of workers' lives are projects that bring increased productivity and reduce health care costs (EDINGTON, 2009).

No company can keep operating in the market without a healthy and productive workforce. Corporate profits are directly connected with the productivity of their human capital. Thus, any reason that may cause the employee to miss work or produce less is of utmost importance.

According to O'Toole and Lawler (2006), an ill employee who chooses to go to work, costs the equivalent of U.S. \$ 255 per year in lost productivity, reaching in total a loss of $\$ 180$ billion annually to U.S. companies.

Thus, this study sought to search the frequency of the following factors that affect employees' work: health problems/ illnesses, existence of a sick family member, financial problems, working environment, psychological and emotional problems and sleep.

Therefore, it is expected that the research will contribute to the search for improvements in the strategies used by companies when it comes to productivity and presenteeism. It is also hoped, that this research will encourage studies in corporate environment with respect to productivity, presenteeism and sleep. 
DOI: 10.14807/ijmp.v5i2.114

\section{PRODUTICTIVITY AND PRESENTEEISM}

Employee productivity is directly related to the success of a company; therefore, whatever the reason that interferes with that performance will reach the company as a whole. i.e., both the lack of work force, as well as the minimization of workers' performance is problems for the organization.

Thus, it is understood by absenteeism the absence from the official working day for reasons related to ill health. Fonseca (2009) clarifies that this absence may be due to scattered faults, compensation and absence of short and long term disability.

Besides absenteeism, which is an older term and further explored in the literature, there is also presenteeism. It is a latest terminology, which is characterized by the inability to produce what should be, or what would be its capacity, due to health problems, but this reason does not take the employee to be absent from the workplace (FONSECA, 2009). So, presenteeism is when people are present in the workplace, but due to problems of physical or psychological nature, cannot fully comply with their functions (HEMP, 2004 apud FONSECA, 2009). Hemp and Shamansky (2004, 2002 apud FONSECA, 2009, p.7) state that:

Presenteism limits productivity not only in terms of quantity but also in quality of work and this can be measured by decrease in production, failure to maintain production standard errors and decreased attention at work, among others.

It is of paramount importance to clarify that the term presenteeism and studies addressing this issue is recent, so it lacks quantitative data and even an internationally recognized protocol that is trustworthy and fulfilling the task of measurement. About the fragility of studying and measuring presenteeism, Fonseca (2009, p. 7) studied Mattke et al. (2007) analyzed that:

The quantification of presenteeism is still under development. According to a recent literature review related to instruments used to measure self-reported presenteeism, lacking well-established and validated methods to convert the lost productivity in monetary estimates, and concludes that the challenges to measure presenteeism far exceeds the measure of absenteeism, especially because many professions do not have their results easily measurable. 


\section{FACTORS THAT AFFECT PRODUCTIVITY}

According to Whitaker (2001, p. 423), among the factors that affect health and quality of life and, consequently, the performance of an employee at work, are:

- Social insurance systems, benefit payments and medical certification practices, which influence work participation;

- Occupational safety, availability of alternative employment and attendance, which affect economic climate;

- Organizational factors, such as firm size, personnel policies and procedures affecting service management;

- Job satisfaction, job stress and psychosocial work environment, which affect service;

- Individual factors such as personality, social support, marital status and health problems affecting attendance.

Health is when the body is in homeostasis, i.e., in a harmonious balance, wellbeing between the physical, social and mental aspects of a human being. Health is not limited to the absence of disease; it also involves quality of life: "The World Health Organization (2010) scales health, welfare and safety as fundamental aspects for productivity, competitiveness and the sustainability of enterprises." (BAPTISTA, 2010, p.3)

Fonseca (2009) refers to Aldana (2001) saying that "the result is used to describe financial expenses related to the employee and they can be included in two main categories: cost of health care and productivity." The author further states that:

The loss of worker productivity resulting from health problems is an indirect measure of the cost of health care for businesses, and is usually assessed by absenteeism and job performance measures, commonly described as being difficult to quantify (FONSECA, 2009).

Based in Burton et al. (1999), Fonseca (2009) mentions the cost of employee health, saying: 
DOI: 10.14807/ijmp.v5i2.114

Productivity measurement is not largely assessed by corporations; when evaluating the impact of health care costs, the figures used are usually those raised directly by the demand for health care, which are much easier to quantify and investigate than indirect ones.

It is known that psychological disorders such as stress and depression impact on employee productivity and are considered factors that influence the occurrence of work accidents and occupational disease. Dewe and Cooper (2008) and Stewart et al. (2003) confirmed the existence of this causality in their research. According to a study by Tavares, Kamimura and Innocent (2010), the changes in the working world of the XXI century attach great emotional pressure on workers and, therefore, have annually increased psychological disorders resulting from work. Thus, the authors analyzed the data available in source Dataprev and concluded that stress was the disorder that has increased over 2005-2008 among psychological disorders and occupational diseases and this list already includes sleep disturbance.

Marques and Moraes (2004) suggested that individuals are becoming more vulnerable to psychosomatic illness due to pressures generated in the workplace. The Ministry of Health in Brazil and the Pan American Health Organization (BRAZIL, 2001), according to Decree No. 1,339, of November 18, 1999, recognized and presented a list of 12 mental and behavioral disorders related to work which may affect workers: a) Dementia in other diseases classified elsewhere b) delirium superimposed on dementia is not as described, c) mild cognitive impairment, d) organic personality disorder e) organic mental disorder or unspecified symptomatic disorder f) chronic alcoholism; g) depressive episodes; h) state of post-traumatic stress; i) neurasthenia; j) other specified neurotic disorders k) disorder of the sleepwake cycle due to non-organic factors) burnout or burnout syndrome.

The main symptoms of stress are: nervousness, anxiety, depression, irritability, fatigue, anger, stomach pain, change in sleep, pain in the chest and neck muscles (COUTO, 1987).

Alday (2000, p. 13) further exemplifies, saying that "it is a dynamic puzzle, whose pieces are embedded every day, every month and year, not mounted at once, in the development of so-called plan ", i.e., involves long sense of well-being and comfort and satisfaction of a balance between family life, loving, social, environmental aesthetics to the very existential. (MINAYO; HARTZ; BUSS, 2000). 


\section{BEHAVIORAL DEFINITION OF SLEEP}

Sleep is a temporary physiological state that can be recognized by monitoring and suppression of decrease in metabolic rate. According to Fernandes (2006, p. 157), sleep is a "special physiological state that occurs cyclically in a wide variety of living beings in the animal kingdom, having been observed behaviors of rest and activity." Still, according to the author, there are four criteria for defining sleep behavior: decreased movement, decreased responsiveness to stimulus of low intensity, typical posture and reversibility between states of wakefulness and sleep.

Sleep disorders can occur for increase, decrease or change of pace from the normal pattern of sleep and wakefulness. Sleep disorders from work relate to working conditions to which the worker is exposed and altering its cycle of sleep and wakefulness. Among the most common reasons include exposure to work situations that affect the emotional, psychological and physical, which could cause a sleep disorder. It is also known that exposure to certain chemicals that cause irritation to the airways, or causing bouts of chronic allergies, also interferes with sleep and is the main cause of sleep disorders and is the result of the work shift changes, in other words, the turnover time of the working day, considered the main culprit when it comes to sleep disorders.

The onset of sleep disorders, including insomnia, excessive sleepiness, sleep apnea, narcolepsy and restless legs syndrome, are common indicators of the performance of labor and night shift because they affect health and thus the quality of life and work performance.

\section{RECENT STUDIES OF CORPORATE HEALTH MANAGEMENT}

Recent studies of corporate health management show the impact of health on productivity and the financial consequences of this link. As this subject is very new in Brazil, there are not many completed surveys. Thus, the research presented has been developed in other countries.

Cooper and Dewe (2008), using the statistical source Health \& Safety Executive, in his research showed that in 2006/07, almost 30 million days were lost due to work-related diseases, stress, depression or anxiety accounted for 13.8 million days lost. 
Musich et al. (2006) sought to investigate the impact of factors related to the corporate environment, the risks to health and medical conditions on productivity, from the historical perspective of 8000 employees in ten different Australian companies. The research revealed that poor working conditions, ineffective management, leadership with low life quality influence the rate of presenteeism.

The study by Stewart et al. (2003) demonstrated that $85 \%$ of the costs of reduced productivity are explained by reduced performance while at work and that depression is responsible for $48 \%$ of this reduction in productivity. The authors also comment that this reduced productivity caused by the depression of employees, costs Americans a value of $\$ 44$ billion a year.

Boles, Peltier and Lynch (2004) conducted a study with a sample of 2264 employees of the same company, seeking to provide evidence for the relationship between health risks and productivity of these workers. The authors concluded that people with more risk factors reported greater loss of productivity, indicating a greater reduction in individuals with diabetes (absenteeism) and stress (presenteeism).

Burton et al. (2005) used a brief version of the Work Limitations Questionnaire along with an assessment of risk to health in a sample of 28,375 employees of a company. The objective of the research was to study the impact of risk factors for the health of workers and their reduced productivity (presenteeism). The result showed that dissatisfaction with life, job dissatisfaction, poor health and stress have a greater association with presenteeism, and each additional risk factor was associated with a reduction in productivity of $2.4 \%$. Individuals who had medium and high risk were $6.2 \%$ and $12.2 \%$, respectively, less productive than low risk. The estimated cost of this lost productivity was $\$ 99$ million for medium risk and 185 million dollars for the high-risk, or U.S. \$ 1,392 and U.S. \$ 2,592 per employee. Another finding of the survey was that anyone who has risk factors for moderate (low level of physical activity and overweight) has decreased productivity by around $6 \%$, while employees with high risk factors (physical inactivity, hypertension, smoking, high cholesterol) are down $12 \%$.

Another study by Burton and others (2006), using the same survey instrument, but in a sample of 7,026 employees of a financial services company, has come to the conclusion that each risk factor implies a reduction in productivity $1.9 \%$ over time and estimated \$ 950 annual per risk. 
INDEPENDENT JOURNAL OF MANAGEMENT \& PRODUCTION (IJM\&P)

http://www.ijmp.jor.br

v. 5, n. 2, February - May 2014.

ISSN: 2236-269X

DOI: 10.14807/ijmp.v5i2.114

A study of more than 12,000 employees of the Dow Chemical Company revealed that emotional problems were the major source of productivity loss compared to a range of other chronic conditions, reducing worker performance by approximately 36\% (PROCHASKA et al. 2011).

Another research conducted at the Dow Chemical Company in the United States, which used the Stanford presenteeism scale and employee data such as demographics, medical and pharmacy claims, smoking, risk factors biometric health records payroll and type of work, revealed that almost $65 \%$ of respondents reported having one or more chronic conditions surveyed. The most common were allergies, arthritis / joint pain or stiffness and pain in the back or neck. Absenteeism associated with a chronic condition ranged from 0.9 to 5.9 hours in a period of four weeks, and presenteeism ranged from $17.8 \%$ to $36.4 \%$. The total cost of 10 major chronic conditions was $10.7 \%$ of the total labor cost of the Dow in the United States (Collins et al., 2005).

Checking if sickness presenteeism results in later impacts in sickness absenteeism was the research goal of Bergstrom et al. (2009). The result was that in the research on more than five occasions during the base year 2000, presenteeism was a statistically significant risk factor for the occurrence of medical licenses in 2002 and 2003. Thus, the authors concluded that sickness presenteeism can lead to absenteeism due to illness in the future.

Allen, Hubbard and Sullivan (2005) investigated the impact of pain in employee productivity, with a sample of 1,039 respondents. The findings of the research were: $28.6 \%$ of workers reported some type of pain; workers with severe pain are increased by five times in restricting work-induced health, pain control is worse for those with severe pain; employees reported having pain miss about three days of work (presenteeism) and two days (absenteeism) productivity in a month, the best starting point of interventions should be derived from musculoskeletal diseases pains.

The Hertz et al. (2004) aimed to investigate the association between obesity, cardiovascular risk factors and labor constraints. They found that obesity increased $43.8 \%$ from $1988-1994$ to $1999-2000$ and now affects $29.4 \%$ of workers, obese workers have higher prevalence of work limitations $(6.9 \%$ versus $3.0 \%$ among workers of normal weight), hypertension (35.3\% versus $8.8 \%)$, dyslipidemia $(36.4 \%$ 
DOI: 10.14807/ijmp.v5i2.114

versus $22.1 \%)$, type 2 diabetes $(11.9 \%$ versus. $3.2 \%)$ and the metabolic syndrome $(53.6 \%$ versus $5.7 \%)$. That is, the impact of obesity on the work limitation is 4 times associated with hypertension, 1.65 times associated with dyslipidemias, diabetes 3.7 times, 9.4 times greater metabolic syndrome.

\section{METHODS}

This study is characterized as an exploratory and quantitative approach. In the design, the strategy case study was used. According to Marconi and Lakatos (2002), the reason for conducting a quantitative research is to find out how many people in a given population share a feature or group of features. According to Marconi and Lakatos (2002), the reason for conducting a quantitative research is to find out how many people in a given population share a feature or group of features.

An exploratory research can be defined according to Marconi and Lakatos (1993) with the objective of strengthening the relationship with the problem studied, in other words, providing familiarity with the problem, making it explicit or allowing the development of hypotheses. It often takes the forms of Bibliographic Research and Studies.

Based on the technical procedures used, this research fits into a case study because, according to Yin (2005, p. 32), "a case study is an empirical inquiry that investigates a contemporary phenomenon within its real-life context especially as the boundaries between phenomenon and context are not clearly defined".

The case study was conducted in a private industry manufacturing branch, located in the Paraíba Valley, with more than 500 employees (large company, ranking second SEBRAE). The company currently has 5400 registered employees and 4900 employees in the plant.

The sample consisted of 125 employees, to which a form containing closed questions on health, quality of life and work was applied. The sample is defined by accessibility, which, according to Vergara (2004) is meant as a sample in which the researcher selects the elements that have access and is used in exploratory or qualitative studies, mainly in case studies; Lwanga and Lemeshow (1991) report that the researcher selects the elements that have access, assuming that they may represent a universe. With regard to the sample, the limitation was the impossibility to apply the forms to the night shift employees. 
DOI: 10.14807/ijmp.v5i2.114

For Marconi and Lakatos (1993), the form offers some alternatives, in which the subject who is answering it chooses the one that best represents his/her situation or point of view, but the filling is done by the researcher. Data were tabulated in the Sphinx software (version 5.1.0.6).

\section{RESULTS AND DISCUSSION}

\subsection{Characterization of the employees' sample}

It is relevant to draw a profile of the sample surveyed for the interpretation of the data found in relation to factors that affect productivity. Therefore, the public sample will be characterized here.

Starting at age factor, one can see that the average age of employees who responded to the form is 31 years and $57.6 \%$ are aged between 20 and 30 years of age, as shown in Figure 1:

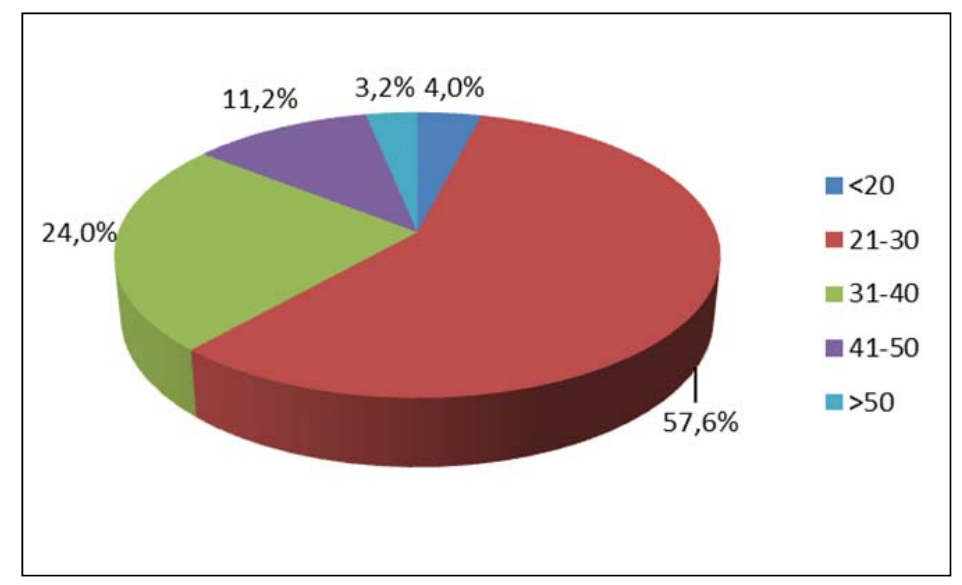

Figure 1 - Graphical representation of age in the sample studied.

Regarding gender, a sample composed predominantly of males $(93.6 \%)$ (Figure 2) was revealed:

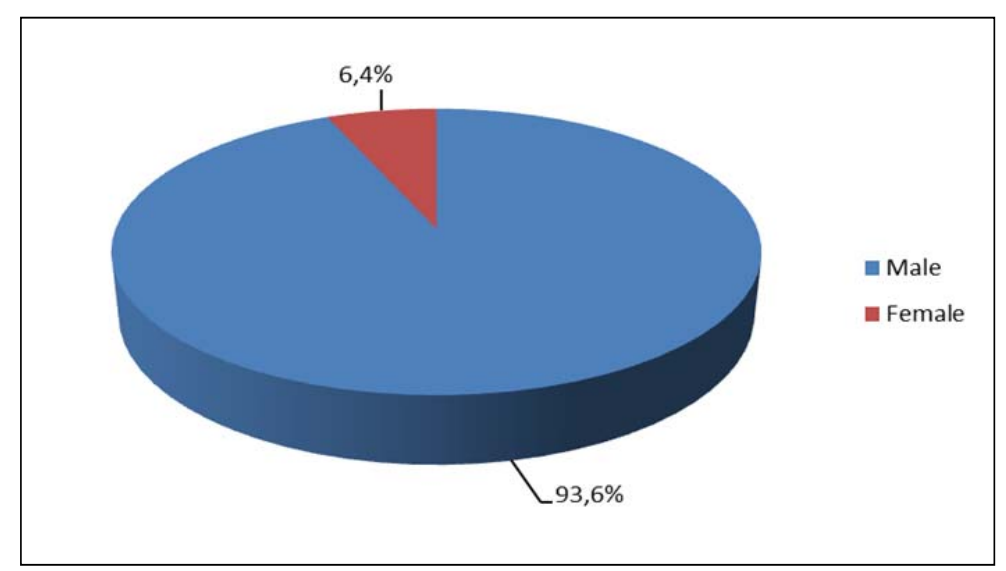

Figure 2 - Graphical representation of the sample by gender. 
INDEPENDENT JOURNAL OF MANAGEMENT \& PRODUCTION (IJM\&P)

http://www.ijmp.jor.br

v. 5, n. 2, February - May 2014.

ISSN: 2236-269X

DOI: 10.14807/ijmp.v5i2.114

As for education, one can see in Figure 3 that more than half of the sample has a high school degree:

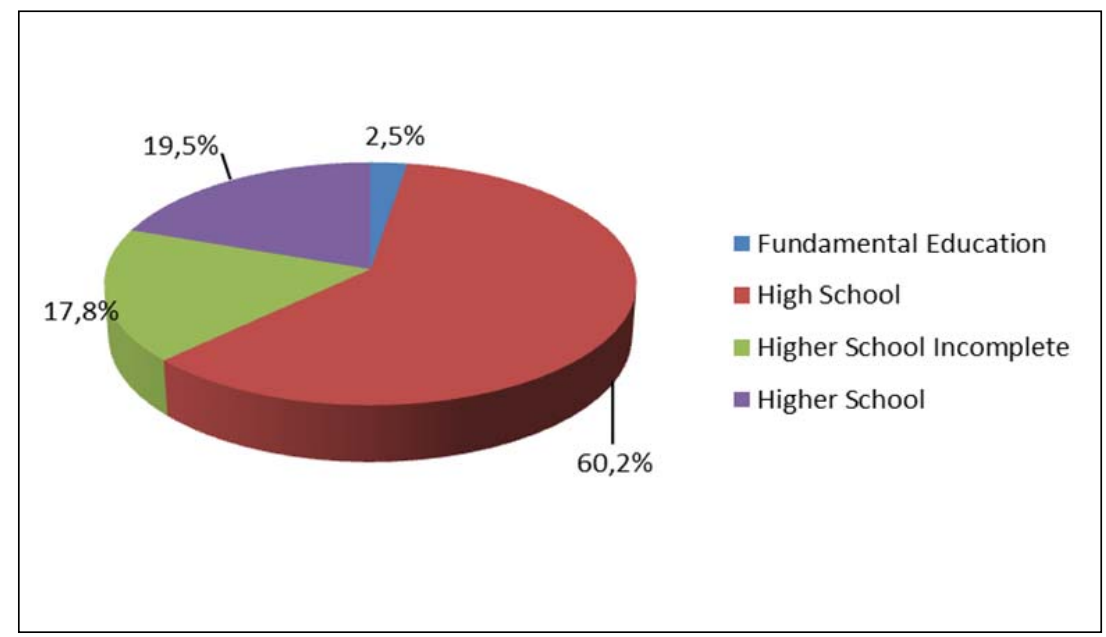

Figure 3 - Graphical representation as to the education of the sample

Regarding the shift, $85.6 \%$ of the sample consisted of workers of the first shift, since the third shift employees(night shift) was not possible (see Figure 4):

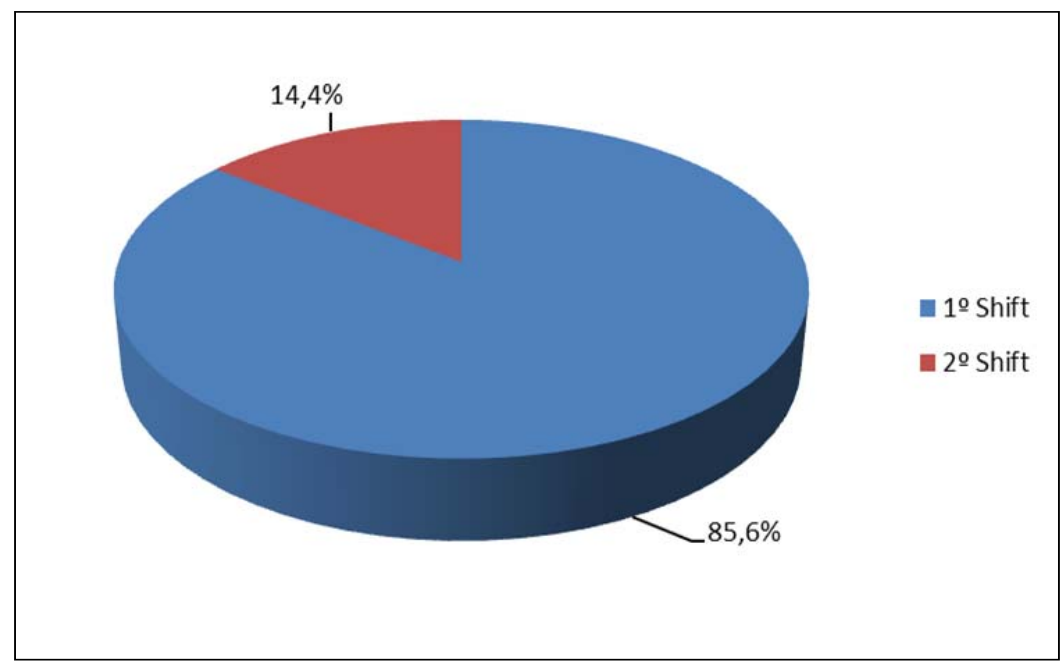

Figure 4 - Graph as to sample shift

Analyzing the item referring to the time that employees have worked in the company, it is clear that more than $60 \%$ of the sample have between two to ten years of work in it, according to Figure 5: 
DOI: 10.14807/ijmp.v5i2.114

Figure 5 - Graphical representation of the sample working time in company (in years)

Figure 6 shows the response obtained for the stress caused by work, in which $41.6 \%$ of the subjects reported having some type of occupational stress:

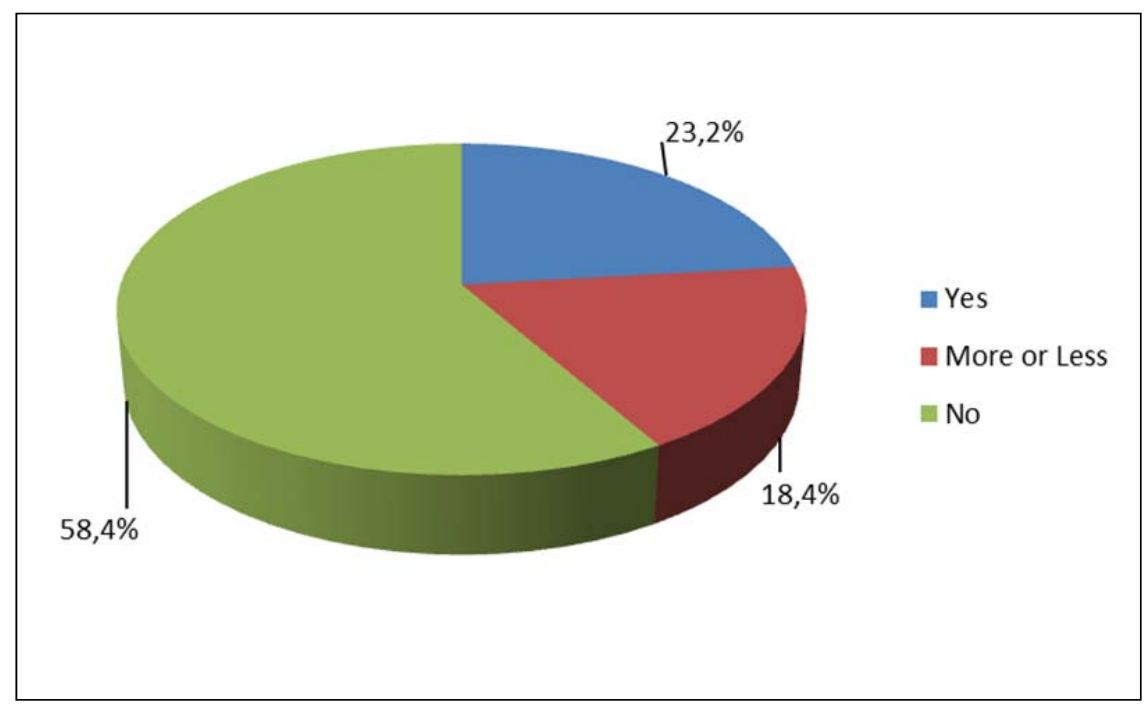

Figure 6 - Graphical representation of workers who reported stress

With respect to the population that has a body mass index higher than expected (BMI), the study sample consisted of $36 \%$ of subjects with weight change (Figure 7): 
DOI: 10.14807/ijmp.v5i2.114

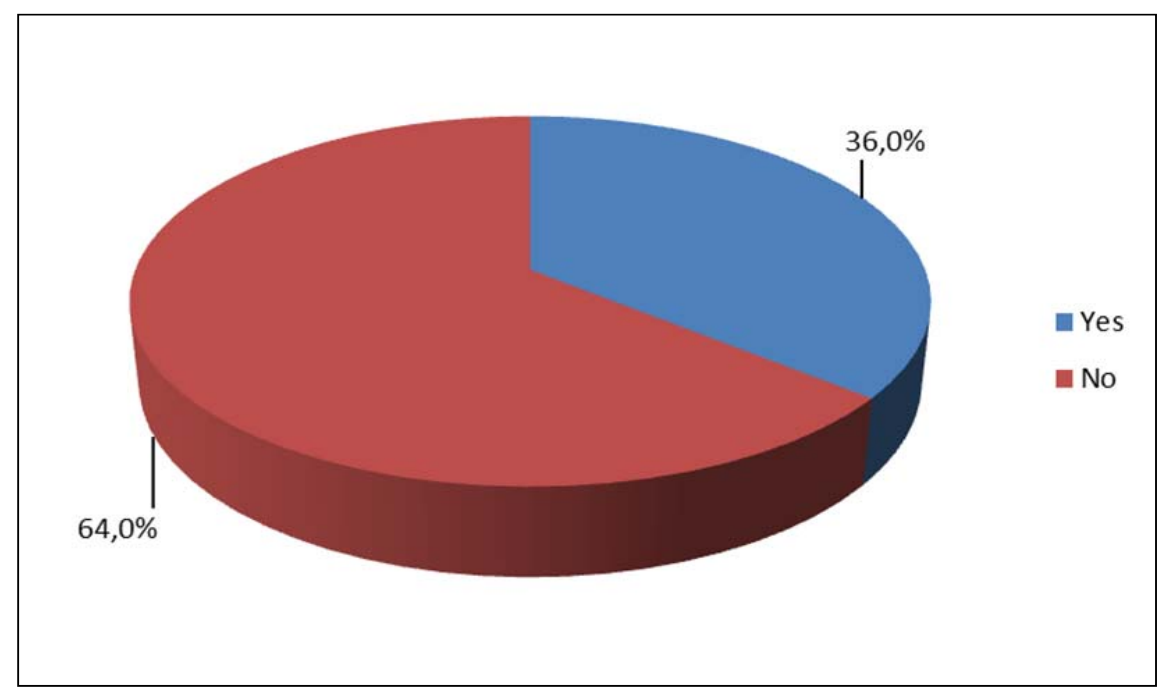

Figure 7 - Graphical representation of the population with above-average weight

With respect to employees performing some sort of physical activity or those who have a sedentary lifestyle, as shown in Figure 8, over $60 \%$ do not exercise:

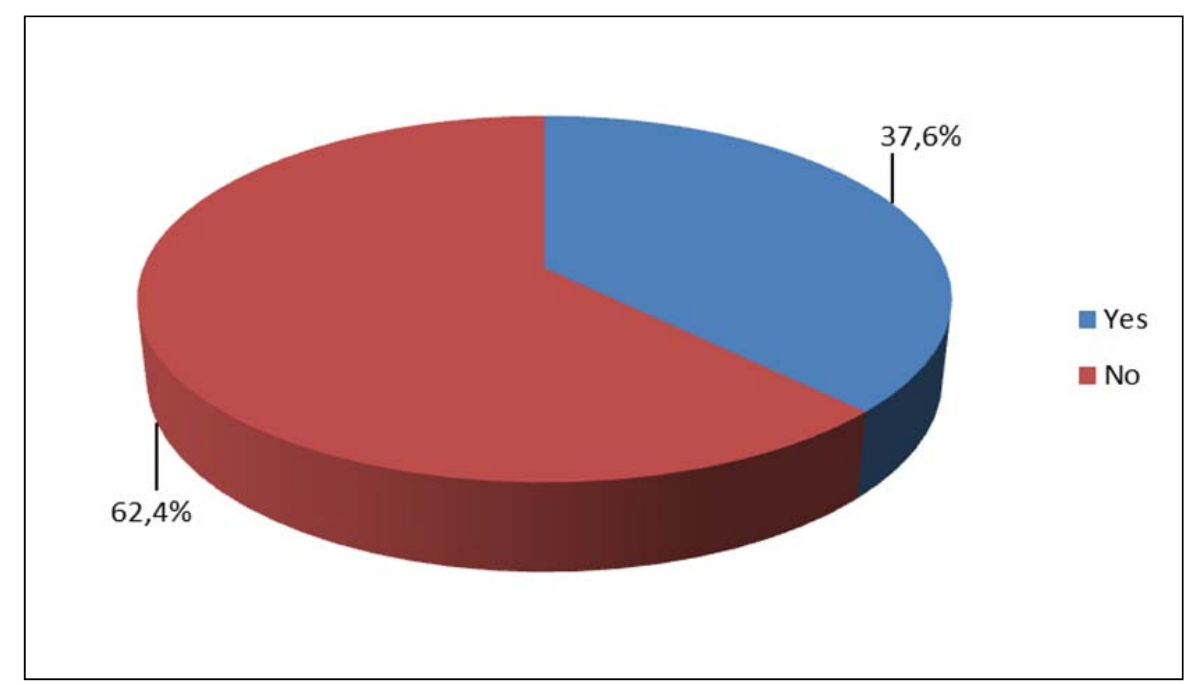

Figure 8 - Graphical representation of the populations which do and do not do physical activity

Under the health aspect, more than $90 \%$ believe they have good health (Figure 9), but in contrast, 51\% reported having a chronic disease, among the chronic diseases studied, allergy was the most recurrent, followed by back pain. During the field research, anxiety and migraine were mentioned, but there is no way to quantify such an account, since they were not entered in the search form (Figure 10): 
DOI: 10.14807/ijmp.v5i2.114

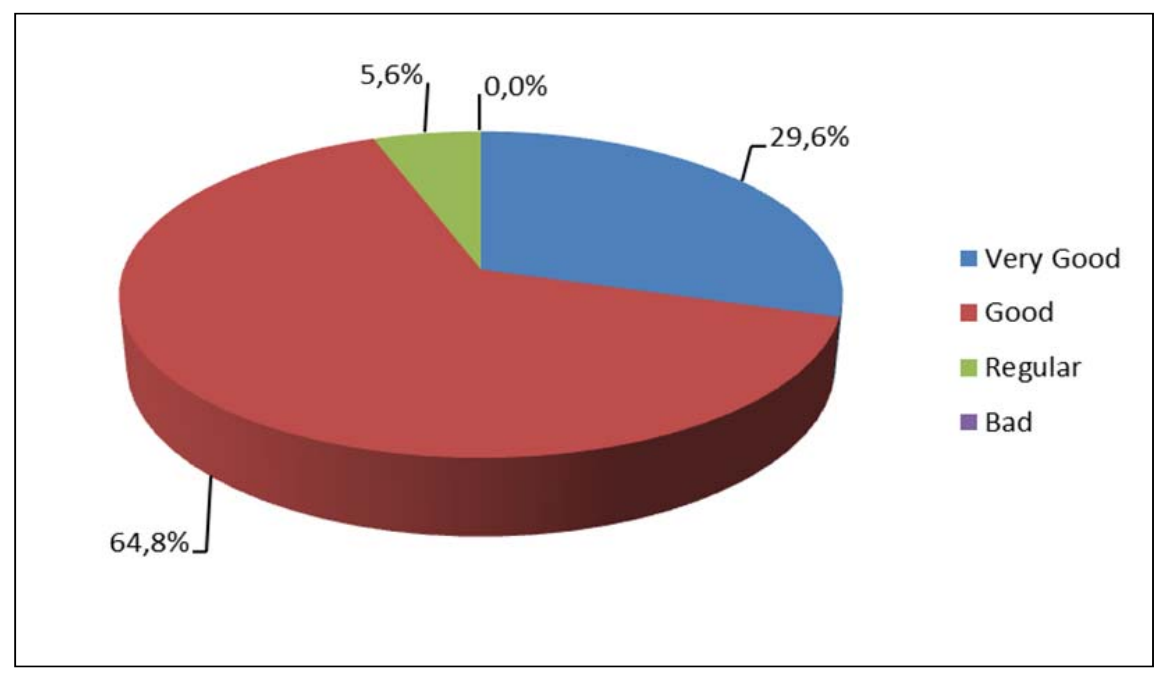

Figure 9 - Graphical representation with respect to health

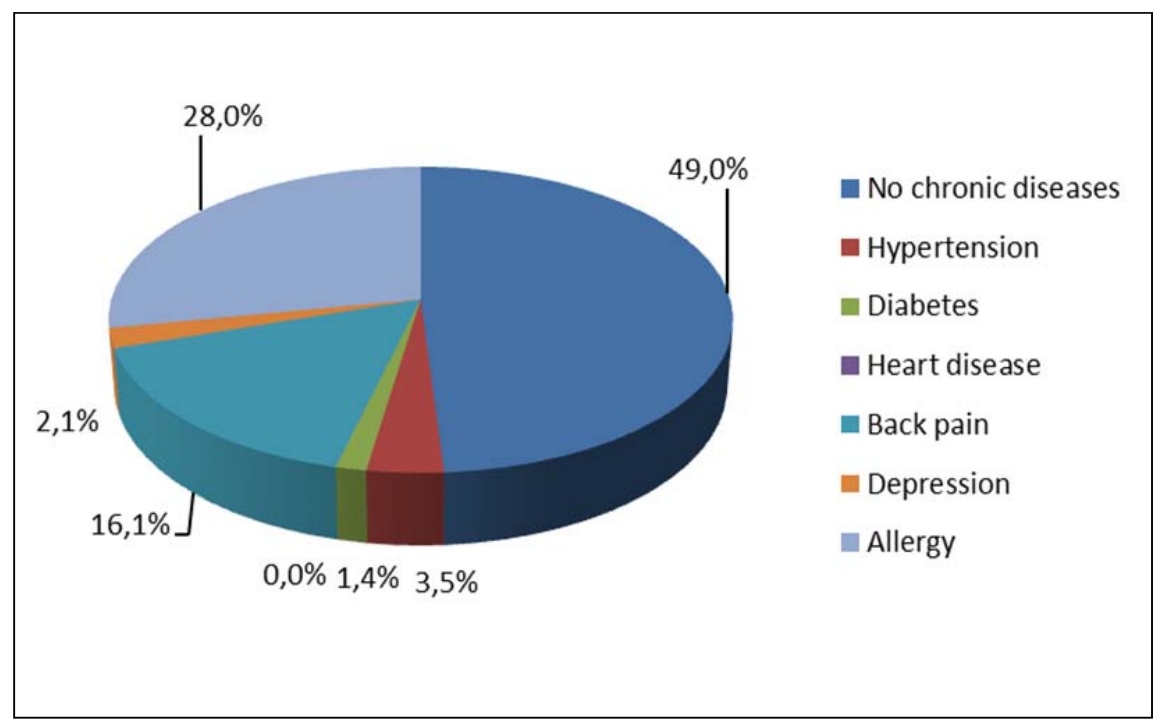

Figure 10 - Graphical representation regarding chronic diseases

Depression is highly relevant today, since this issue has become a national concern because of its high prevalence, 8-25\% (INNOCENT, 2005). The most common symptoms are: depressed mood, loss of interest and pleasure, increased fatigue and reduced activity, and other symptoms - reduced concentration and attention, reduced self-esteem and self-confidence, ideas of guilt and worthlessness; bleak and pessimistic views of the future; ideas or act that harm or lead to suicide, disturbed sleep and decreased appetite. The World Health Organization (HARNOIS 1996 apud SILVA et al., 2009) signals depression as the leading cause of lost work in the world, projecting that by the year 2020, it appears as the leading cause of disability for employees at work.

When asked about the quality of sleep, $33.6 \%$ consider not having a good one. But at the time of listing the characteristics that influence the quality of sleep, 
INDEPENDENT JOURNAL OF MANAGEMENT \& PRODUCTION (IJM\&P)

http://www.ijmp.jor.br

v. 5, n. 2, February - May 2014.

ISSN: 2236-269X

DOI: 10.14807/ijmp.v5i2.114

only $7 \%$ did not report any item, and over $90 \%$ reported having one or more of the characteristics investigated in the act that interferes with sleep (Figures 11 and 12):

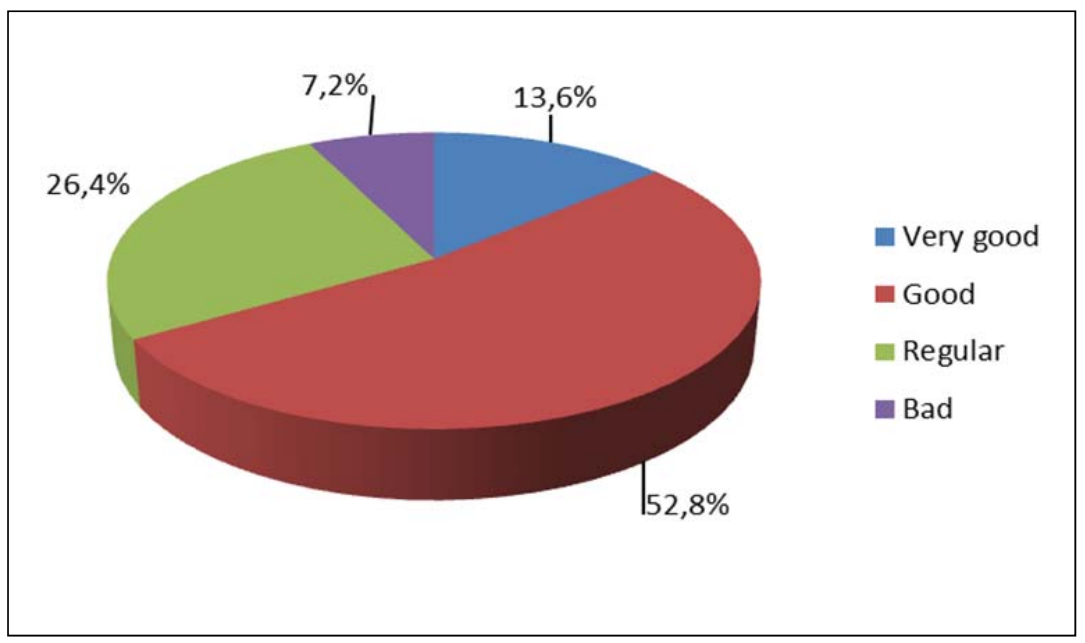

Figure 11 - Graphical representation as to the classification of sleep

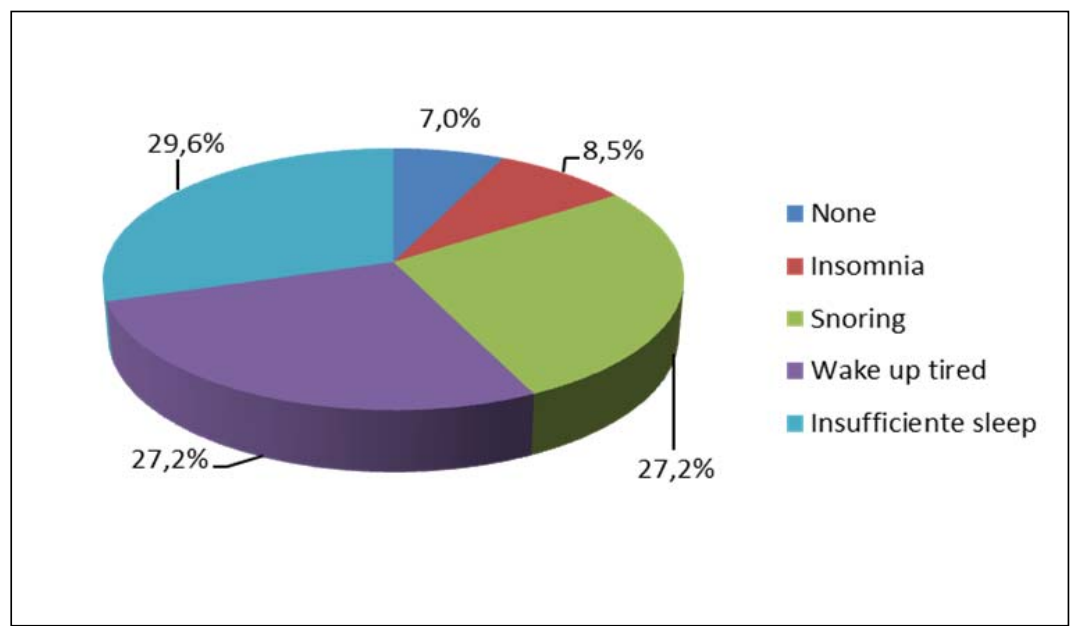

Figure 12 - Graphical representation as to the items that affect the quality of sleep able 1 , shows company time versus quality of sleep:

Table 1 - Company time x Sleep Quality

\begin{tabular}{|c|c|c|}
\hline $\begin{array}{l}\text { Time working in the } \\
\text { company (years) }\end{array}$ & $\begin{array}{l}\text { Sleep good and very } \\
\text { good }\end{array}$ & Regular sleep and bad \\
\hline $0-1$ & $21,7 \%$ & $19,1 \%$ \\
\hline $2-5$ & $33,7 \%$ & $28,6 \%$ \\
\hline $6-10$ & $30,1 \%$ & $35,7 \%$ \\
\hline $11-20$ & $10,8 \%$ & $11,9 \%$ \\
\hline$>20$ & $3,6 \%$ & $4,8 \%$ \\
\hline
\end{tabular}

\subsection{Factors that affect productivity}

Those who missed work due to illness in the previous year were also researched, and $47 \%$ reported having missed work, as shown in Figure 13: 


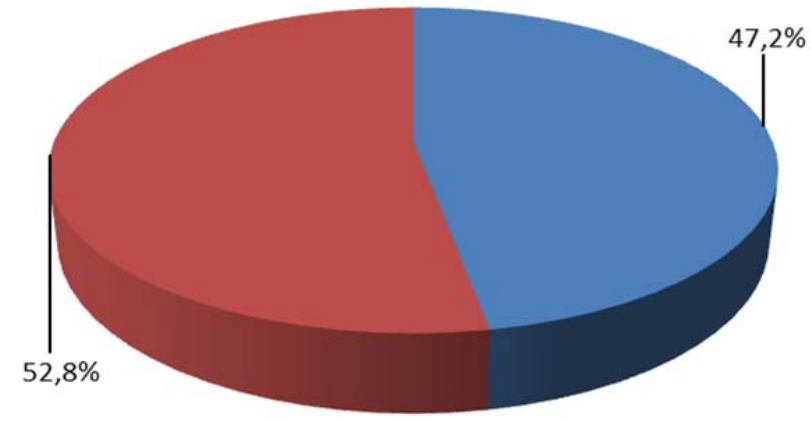

Figure 13 - Graphical representation on absenteeism due to illness in the previous

$$
\text { year }
$$

Confirming the importance of this information, Reis (2001) conducted a study in a large company in the metallurgy field, having as its basis the total data of 6,366 medical certificates. In this research, he came to the following data:

Table 2 - Distribution of sickness up to 15 days

\begin{tabular}{lrr}
\hline Registered Cause & Consolidated (1991 to 1998) \\
\hline (Large Group) & $\mathbf{1}$ & $\mathbf{\%}$ \\
Infectious diseases & 268 & 4,2 \\
Neoplasms & 18 & 0,3 \\
Endocrine and immune diseases & 31 & 0,5 \\
Blood diseases & 9 & 0,1 \\
Mental disorders & 149 & 2,3 \\
Diseases of the nervous system & 244 & 3,8 \\
Diseases of the circulatory system & 195 & 3,1 \\
Respiratory Diseasess & 1124 & 17,7 \\
Digestive diseases & 562 & 8,8 \\
Diseases of the genitourinary system & 174 & 2,7 \\
Complications of pregnancy & 6 & 0,1 \\
Diseases f the skin and subcutaneous tissue & 183 & 2,9 \\
Diseases of the musculoskeletal system & 1190 & 18,7 \\
Deformations and chromosomal abnormalities & 6 & 0,1 \\
Signs and symptoms and ill-defined conditions & 509 & 8,0 \\
Injuries and traumas & 444 & 7,0 \\
Other contacts with health services & 1254 & 19,7 \\
TOTAL & $\mathbf{6 3 6 6}$ & $\mathbf{1 0 0}$ \\
\hline
\end{tabular}

Based on the data presented on the table, the author reached the following values: Direct costs involving medical certificates within 15 days was of approximately U.S. $\$ 905,807.90$. The biggest cost was related to the group of diseases of the musculoskeletal system with U.S. \$203,925.00, followed by respiratory diseases with U.S. $\$ 150,865.00$ and other contacts with health services with U.S. \$ 139,615.70. (REIS, 2001). 
DOI: 10.14807/ijmp.v5i2.114

For examining the factors that impact on productivity and the frequency with which they interfere, workers were asked to give a grade on the frequency of a particular item that interfere with their work. Calculating an average of the responses to each item, inferring weights '1.5', '5,5' and ' 9 ' to the tracks of grades, the highest average for the interference of sleep was obtained (4.2), followed by desktop (3.9) and health problems (3.8), with the lowest average item for emotional problems (2.8). The factor that had the highest percentage of grade $8-10$ is sleep. The range of responses can be seen in Figure 14:

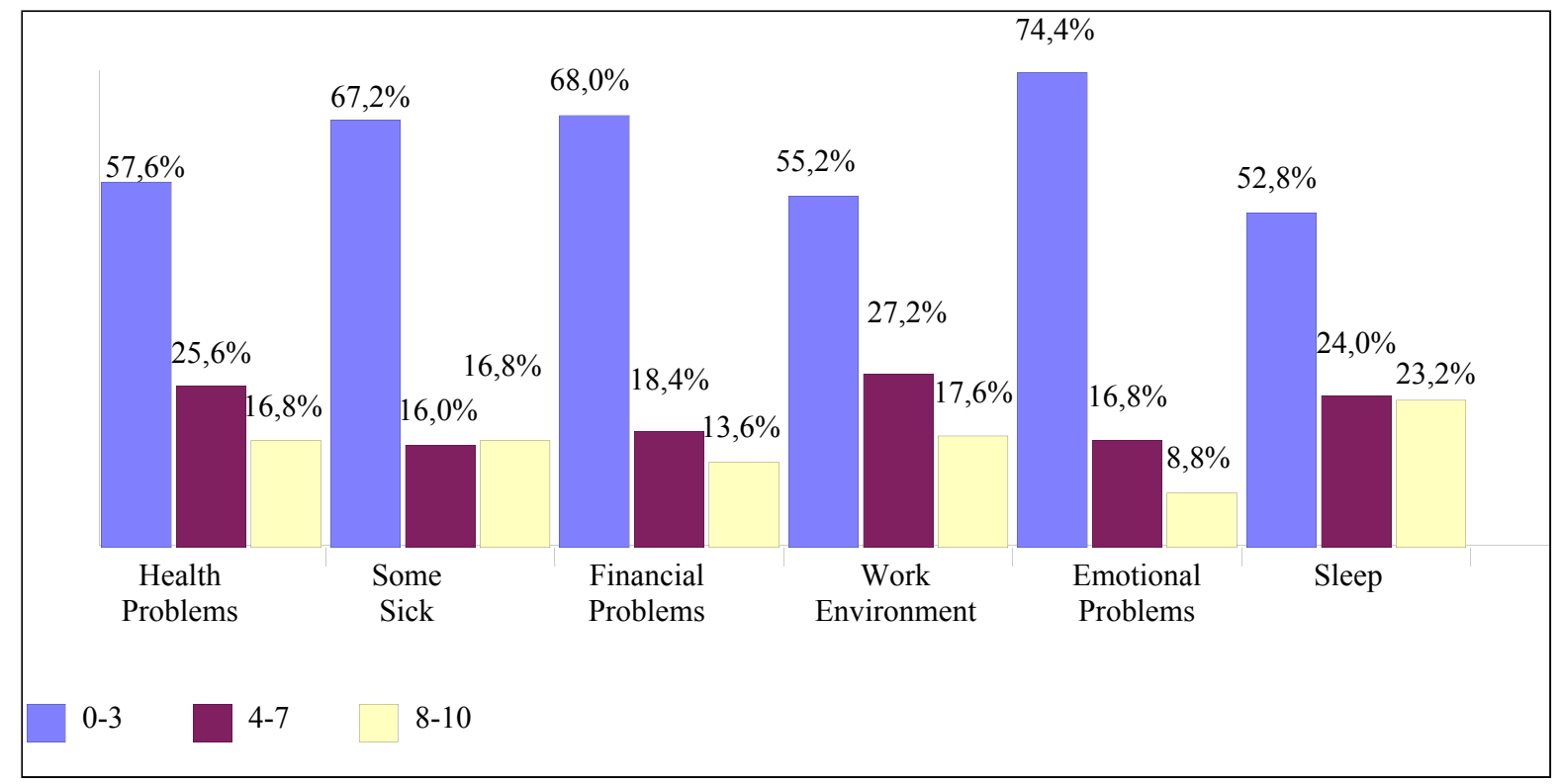

Figure 14 - Graphical representation of the factors that interfere with worker productivity $\mathrm{x}$ grade (quantification)

Although emotional problems have been the factor that showed less interference in productivity among those surveyed, it is known that the change in emotional state can result in bodily symptoms, called psychosomatic illnesses. Rangel (2009, p. 01) addresses the issue:

The emotions that affect the individual in the workplace arising from the clash with the organization of work and can cause disease, comes to be defined as psychosomatic illnesses. The word psychosomatic is a term taken from psyche (denoting the mind, mental processes, and emotional activities) and somatic (soma, meaning something distinct from body and mind).

Study by ISMA-BR (2008) reported that among the main causes of presenteeism, health problems that reduce the productivity of Brazilian workers are: muscle pain $(86 \%)$, sleep problems $(35 \%)$, gastrointestinal pain $(26 \%)$. 
DOI: 10.14807/ijmp.v5i2.114

\section{FINAL CONSIDERATIONS}

From the historical perspective of the workers themselves, this work analyzes some interference factors in the performance of work activity. It can be concluded that sleep among the factors studied, is what most interferes with work. This result was obtained, taking into account that most of the research population is male and it was not possible to include the night shift employees, which would probably demonstrate this finding further.

In spite of the results found, few companies give due attention to presenteeism and recognize the interference of sleep in productivity. Yet there is a reality that companies worry and invest in the quality of sleep of their employees.

After exposure of the findings, some questions arise:

- How to maximize the productivity of human capital reporting tiring waking up and improper sleeping?

- Population overweight, with sleep impairment, sedentary life and may be considered young: what is the influence of these four characteristics on worker health and, consequently, on their productivity in the near future?

Thus, studies of presenteeism and health management, ways of measuring and obtaining indicators of presenteeism, productivity and quality of sleep in the night shift employees will come to add, synergistically toward the improvement of effective productivity management and health employees.

Therefore, this study aims at encouraging discussion in the field of productivity, presenteeism and quality of sleep in organizations, besides encouraging researchers to discuss such topics so that improvements in this field can be made and knowledge in this area can be expanded. Emphasis is also placed on the attention companies should give to such problems.

\section{REFERENCES}

ALDAY, H. E. C. (2000) O Planejamento Estratégico dentro do Conceito de Administração Estratégica. Revista FAE, Curitiba, v. 3, n. 2, p. 9-16.

ALLEN, H.; HUBBARD, D.; SULLIVAN, S. (2005) The burden of pain on employee health and productivity at a major provider of business services. J. Occup. Environ. Med., v. 47, n. 7, p. 658-670.

BAPTISTA, M. J. C. (2010) A cultura de saúde de uma instituição financeira 
nacional conforme a percepção dos profissionais de recursos humanos. 2010. 98p. Final Paper (MBA in Human Resources) - São Paulo: Fundação Instituto de Administração (FIA).

BERGSTROM, G. et al. (2009) Sickness Presenteeism Today, Sickness Absenteeism Tomorrow? A Prospective Study on Sickness Presenteeism and Future Sickness Absenteeism. J Occup Environ Med., v. 51, p. 629-638.

BOLES, M.; PELLETIER, B.; LYNCH, W. (2004) The relationship between health risks and work productivity. J Occup Environ Med., v. 46, n.7, p. 737-745.

BRASIL. Ministério da Saúde do Brasil; Organização Pan-Americana da Saúde no Brasil. Doenças relacionadas ao trabalho: manual de procedimentos para os serviços de saúde, 2001, 580 p. Available in:

http://dtr2001.saude.gov.br/editora/produtos/livros/pdf/02_0388_M1.pdf

BURTON, W. N.; BRANDT-RAUF, P. W. (2008). Health and Productivity. A Review of the Stateof-the Art and Implications for Occupational and Environmental Medicine.

Giornale Italiano di Medicina del Lavoro e Ergonomia, v. 30, n. 1, p. 15-29.

BURTON, W. N. et al. (2006) The association between health risk change and presenteeism change. J. Occup. Environ. Med., v. 48, n. 3, p. 252-263.

BURTON, W. N. (2005) The association of health risks with on-the-job productivity. J. Occup. Environ. Med., v. 47, n. 8, p. 769-777.

COLLINS, J. J. et al. (2005) The Assessment of Chronic Health Conditions on Work Performance, Absence, and Total Economic Impact for Employers. J. Occup.

Environ. Med., v. 47, n. 6, p. 547-557.

COOPER, C.; DEWE, P. (2008) Well-being-absenteeism, presenteeism, costs and challenges. Occup. Med., London, v. 58, n. 8, p. 522-524.

COUTO, H. A. (1987) Stress e qualidade de vida dos executivos. Rio de Janeiro: COP.

EDINGTON, D. W. (2009). Zero Trends. Health as a Serious Economic Strategy. Detroit: Health Management Research Center/University of Michigan.

FERNANDES, R. M. F. (2006) The normal sleep. Medicina, Ribeirão Preto, v. 39, n. 2, p. 157-168.

FONSECA, V. R. (2009) Atividade física, absenteísmo e demanda por atendimento à saúde de funcionários de indústria automobilística de São Caetano do Sul.2009. 141p. Tese (Doutorado em Ciências). São Paulo: Universidade de São Paulo.

HEMP, P. (2004). Presenteeism: At work but out of it. Harvard Business Review, $n$. 82, p. 49-58.

HERTZ, R. P. et al. (2004) The impact of obesity on work limitations and cardiovascular risk factors in the U.S. Workforce. J. Occup. Environ. Med., v. 46, n. 12, p. 1196-203.

INOCENTE, N. J. (2005) Síndrome de Burnout em professores universitários do Vale do Paraíba, (SP). 2005. 248p. Thesi (PhD in Medical Sciences). Campinas: Universidade de Campinas (Unicamp).

ISMA-BR, International Stress Management Association (2009) Presenteísmo. 
Brasil, Available in: <http://www.ismabrasil.com.br/artigos>. Access in: 18 jan. 2012. LAWLER, E. E.; O'TOOLE, J. (2006) America at work: choices and challenges. New York: Palgrave Macmillan.

LWANGA, S. K.; LEMESHOW, S. (1991) Sample size determination in health studies: a practical manual. Geneva:World Health Organization.

MARCONI, M. de A.; LAKATOS, E. M. (2002) Técnicas de pesquisa: planejamento e execução de pesquisas; amostragens e técnicas de pesquisa; elaboração, análise e interpretação de dados, 5. ed. São Paulo: Atlas.

MARCONI, M. de A. (1993) Fundamentos de metodologia científica. São Paulo: Atlas.

MARQUES, A. L.; MORAES, L. F. R. de. (2004) Desenvolvimento Gerencial através de Cursos de Longa Duração: um estudo sobre a percepção de eficácia dos cursos de MBA e suas relações com a qualidade de vida e estresse no trabalho. In: ENANPAD, n. 28,2004 , Curitiba. Anais..., Curitiba.

MINAYO, M. C. de S.; HARTZ, Z. M. de A.; BUSS, P. M. (2000) Qualidade de vida e saúde: um debate necessário. Ciênc. saúde coletiva, Rio de Janeiro, v.

5, n.1. Available in: <http://www.scielo.br/scielo.php?script=sci_arttext\&pid=S1413$81232000000100002 \&$ Ing=en\&nrm=iso $>$. Access in: 28 Dec. $20 \overline{11}$.

MUSICH, S. et al. (2006) The association of corporate work environment factors, health risks, and medical conditions with presenteeism among Australian employees. Am J Health Promot., v. 21, n. 2, p. 127-136, Nov./Dec.

PROCHASKA, J. O. et al. (2011) The well-being assessment for productivity: a wellbeing approach to presenteeism. J Occup Environ Med., v. 53, n.7, p. 735-742.

RANGEL, F. B. (2009) Sintomas Psicossomáticos e a Organização do Trabalho: um estudo em uma IES. In: ENANPAD, n. 33, 2009, São Paulo. Anais..., São Paulo: Enanpad, 2009.

REIS, P. (2001) Uso Gerencial da Informação de Saúde no Ambiente de Trabalho: análise epidemiológica das causas de absenteísmo. In: CONGRESSO ANAMT, 11, Belo Horizonte. Anais..., Belo Horizonte: Anamt, 2001.

SILVA, G. G. J. e outros. (2009) Considerações sobre o transtorno depressivo no trabalho. Revista Brasileira de Saúde Ocupacional; v. 34, n.119.

STEWART, W. F. et al. (2003) Custo do tempo de trabalho produtivo perdido entre trabalhadores com depressão nos EUA. JAMA, v. 289, p. 3135-3144.

TAVARES, R. da S. C. R.; KAMIMURA, Q.; INOCENTE, N. (2010) Transtornos psicológicos do Anuário Estatístico da Previdência Social de Acidentes do Trabalho. In: MOSTRA DE PÓS-GRADUAÇÃO DA UNIVERSIDADE DE TAUBATÉ, 11, Anais..., Taubaté: Mpg, 2010.

VARGAS, V. do C. C. de et al. (2008) Avaliação dos intangíveis: uma aplicação em capital humano. Gest. Prod., São Carlos, v.15, n.3. Available in: $<$ http://www.scielo.br/scielo.php?script=sci_arttext\&pid=S0104530X2008000300015\&Ing=en\&nrm=iso>. Access in: 03 Jun. 2011.

VERGARA, Sylvia C. (2004) Projetos e Relatórios de Pesquisa em Administração, 5 ed. São Paulo: Atlas. 
INDEPENDENT JOURNAL OF MANAGEMENT \& PRODUCTION (IJM\&P)

http://www.ijmp.jor.br $\quad$ v. 5, n. 2, February - May 2014. ISSN: 2236-269X

DOI: 10.14807/ijmp.v5i2.114

WHITAKER, S. C. (2001) The Management of Sickness Absence. J Occup Environ Med., v. 58, n. 6, p. 420-424.

YIN, R. K. (2001) Estudo de caso: planejamento e métodos, 2. ed. Porto Alegre: Bookman. 